\title{
PENERAPAN MODEL GROUP INVESTIGATION TERHADAP KEMAMPUAN MENULIS HAL-HAL PENTING DALAM WAWANCARA OLEH SISWA SEKOLAH MENENGAH PERTAMA
}

\begin{abstract}
Abstrak
Menulis hal-hal penting atau isi dalam wawancara merupakan kegiatan mencatat pokok-pokok informasi mulai dari topic pembicaraan, tujuan, dan hal-hal penting lainnya yang dirangkai menjadi sebuah kesimpulan melalui proses menyimak yang memerlukan konsentrasi dan perhatian penuh dari pendengar untuk memahami isi pembicaraan yang disampaikan. Tujuan penelitian ini adalah untuk mengetahui apakah peningkatan kemampuan siswa menulis hal-hal penting/isi dalam wawancara melalui model Group Investigation. Subjek dalam penelitian ini adalah siswa kelas VII semester II Sekolah Menengah Pertama. Metode penelitian ini adalah metode Penelitian Tindakan Kelas (PTK) dengan prosedur yaitu perencanaan (Planning), pelaksanaan (Action), pengamatan (Observation), dan refleksi (Reflection). Berdasarkan hasil penelitian ini ternyata ada peningkatan kemampuan siswa menulis hal-hal penting/isi adalah wawancara melalui model Group Investigation. Pada siklus I peningkatan kemampuan siswa menulis hal-hal penting/isi dalam wawancara mendapat nilai terendah yaitu 30 dan nilai tertinggi 80 dengan rata-rata 58,65. Pada siklus II peningkatan kemampuan siswa menulis hal-hal penting/isi dalam wawancara nilai terendah yaitu 70 dan tertinggi

95 dengan rata-rata 81,73 .
\end{abstract}

Kata kunci: Model Group Investigation, Menulis Hal Penting, Wawancara

\begin{abstract}
Writing important things/content in the interview is an activity to record the main points of information starting from the topic of conversation, objectives, and other important things that are arranged into a conclusion through a listening process that requires the concentration and full attention of the listener to understand the contents of the conversation to be delivered. The purpose of this study is to find out whether the increase in students' ability to write important things/content in interviews through the Group Investigation model. The subjects in this study were students of class VII semester II of junior high school. This research method is a Classroom Action Research (CAR) method with procedures that are planning, implementation, observation, and reflection. Based on the results of this study, it turns out there is an increase in
\end{abstract}

\footnotetext{
${ }^{1}$ Prodi Bahasa Indonesia, IKIP Gunungsitoli

Alamat email: trisman_harefa@ymail.com
} 
the ability of students to write important things/content is an interview through the Group Investigation model. In cycle, I, the students' ability to write important things/contents in the interview got the lowest score of 30 and the highest score of 80 with an average of 58.65. In cycle II, the students' ability to write important things/contents in interviews was the lowest, 70 and the highest 95 with an average of 81.73 .

Keywords: Model Group Investigation, Writing Important Things, Interview.

\section{PENDAHULUAN}

Menulis merupakan salah satu keterampilan berbahasa yang saling berkaitan dan saling melengkapi dengan keterampilan yang lain (menyimak, berbicara, membaca, dan menulis). Selain itu, menulis merupakan suatu proses kreatif menuangkan gagasan dalam bentuk bahasa tulis dengan tujuan memberitahu, meyakinkan dan menghibur (Damlan, 2012:3).

Menurut Kusmayadi (2007:5) bahwa menulis dapat diartikan sebagai kegiatan menyusun serta merangkaikan kalimat sedemikian rupa agar pesan, informasi, serta maksud yang terkandung dalam pikiran, gagasan dan pendapat penulis dapat disampaikan dengan baik. Kegiatan menulis menuntut adanya kemampuan untuk menyusun atau mengorganisasikan buah pikiran atau ide-ide kedalam rangkaian kalimat yang logis dan terpadu sehingga mengandung sebuah makna.

Berdasarkan pendapat diatas, dapat disimpulkan bahwa menulis adalah proses menciptakan lambang-lambang tulisan yang memiliki makna lewat berpikir sehingga dapat menghasilkan tulisan yang baik. Kegiatan menulis dapat memperluas atau mengembangkan gagasan mengenai sesuatu yang ditulis melalui proses mengaitkan antar kata, kalimat, paragraph maupun antara bab secara logis agar dapat dipahami. Menulis hal-hal penting dalam wawancara merupakan kegiatan mencatat pokok-pokok informasi mulai dari topik pembicaraan, tujuan, dan hal-hal penting lainnya yang dirangkai menjadi sebuah kesimpulan (Anindyarini, 2008:132). Kegiatan ini memerlukan konsentrasi dan perhatian penuh dari pendengar untuk memahami isi pembicaraannya yang disampaikan dalam isi wawancara dan menulis hal-hal penting dalam isi wawancara.

Ada beberapa masalah yang terjadi adalah bahwa kemampuan siswa dalam menulis hal-hal penting/isi wawancara masih sesuai dengan yang diharapkan karena beberapa faktor, antara lain : a). siswa kurang mampu menentukan topik dalam isi wawancara; b). siswa kurang mampu menentukan tujuan dalam isi sebuah wawancara; c). siswa memiliki kemampuan yang berbeda-beda dalam menulis hal-hal penting/isi wawancara; dan d). siswa yang masih memiliki kemampuan terbatas dalam menulis halhal penting/isi wawancara membuat proses pembelajaran terkesan pasif (Zagoto, dkk., 2018; Sarumaha, 2018; Dakhi, O., 2013). 


\section{METODE}

\section{Lokasi Penelitian}

Lokasi penelitian tindakan kelas ini dilaksanakan di Sekolah Menengah Pertama Desa Lahusa, Kecamatan Sirombu, Kabupaten Nias Barat. Adapun alasan penulis memilih lokasi ini yaitu:

a. Lokasi penelitian mudah dijangkau oleh peneliti.

b. Pendekatan awal yang dilakukan oleh peneliti karena rencana ingin mengabdi disekolah tersebut pada masa yang akan datang.

c. Peneliti ingin menerapkan model Group Investigation (GI) agar dapat meningkatkan kemampuan siswa khususnya pada materi menulis hal-hal penting/isi dalam wawancara di Sekolah Menengah Pertama.

\section{Sabjek penelitian}

Subjek dalam penelitian ini adalah siswa kelas VII semester II Sekolah Menengah Pertama. penelitian memilih subjek penelitian ini karena kurang mampu menulis hal-hal penting/isi dalam wawancara, tentunya berdasarkan observasi sebelumnya.

\section{Populasi Dan Pemberikan Sampel}

\section{a. Siklus Pertama}

1. Pertemuan pertama terdiri dari :

a. Tahap perencanaan

Menyusun rencana perlaksanaan pembelajaran pada awal pembelajaran, materi menulis hal-hal penting/isi dalam wawancara, menyiapkan lembar observasi, contoh isi rekaman wawancara dan membuat tes hasil belajar.

b. Tahap tindakan

Kegiatan yang dilakukan dalam tahap ini adalah pelaksanaan pembelajaran yang telah direncanakan dalam rencana pelaksanaan pembelajaran dengan beberapa langkah-langkah yaitu:

1. Peneliti menyampaikan tujuan pembelajaran.

2. Peneliti menggali pengetahuan siswa mengenai materi wawancara.

3. Peneliti menjelaskan pengertian wawancara.

4. Peneliti menjelaskan jenis-jenis wawancara.

5. Peneliti menjelaskan cara menyimpulkan hasil wawancara atau isi wawancara dari narasumber yang yang didengar dari rekaman.

6. Peneliti memberikan contoh rekaman isi wawancara yang diperdengarkan kepada siswa

7. Peneliti menjelaskan penerapan model pembelajaran Group Investigation

8. Peneliti meminta siswa untuk menanyakan materi yang masih belum dipahami

9. Peneliti memberikan kesimpulan materi. 
c. Tahap observasi

Pada tahap observasi ini dilakukan secara bersamaan dengan pelaksanaan tindakan dan pengamat (guru bidang studi bahasa Indonesia) menggunakan lembar pedoman observasi.

d. Tahap refleksi

Pada tahap ini menganalisis hasil observasi, mengevaluasi hasil observasi, menganalisis hasil pembelajaran.

\section{Pertemuan terdiri dari:}

a. Tahap perencanaan

Menyusun rencana pelaksanaan pembelajaran perbaikan pada pembelajaran,yaitu menyiapkan lembar onsevasi,media yang digunakan (alat rekaman) dan daftar penilaian siswa.

b. Tahap tindakan

1. Peneliti menjelaskan maksud pembelajaran dan tugas kelompok.

2. Peneliti menjelaskan kembali materi tentang wawancara dan yang perlu diperhatikan dalam menulis hal-hal penting dalam wawancara.

3. Peneliti membentuk 5 kelompok kecil. Setiap kelompok terdiri dari 5 orang siswa.

4. Peneliti memberikan contoh wawancara yang diperdengarkan lewat rekaman dan meminta siswa menulis hal-hal penting/isi yang terdapat dalam wawancara tersebut dalam bentuk kesimpulan yang singkat dan tepat.

5. Peneliti menyuruh salah satu dari perwakilan dari setiap kelompok menyampaikan hasil diskusi kelompoknya.

6. Peneliti meminta kelompok lain berpatisipasi aktif dengan bertanya dan member tanggapan terhadap hasil diskusi kelompok yang tampil.

7. Peneliti memberikan penjelasan singkat sekaligus memberikan kesimpulan mengenai tugas kelompok yang dibahas.

8. Peneliti meminta siswa setiap kelompok membuat laporan akhir yang telah disempurnakan.

c. Tahap observasi

Pada tahap observasi ini dilakukan secara bersamaan dengan pelaksanaan tindakan dan pengamat (guru bidang studi bahasa Indonesia) menggunakan lembar pedoman observasi.

d. Tahap refleksi

Pada tahap ini menganalisis hasil observasi, mengevaluasi hasil observasi, menganalisis hasil pembelajaran. Data hasil evaluai dianalisis apakah siklus pertama telah tuntas atau tidak.

\section{b. Siklus kedua}

1. Pertemua pertama terdiri dari : 
a. Tahap perencanaan

Menyusun rencana pelaksanaan pembelajaran pada awal pembelajaran, menyiapkan lembar observasi, materi menulis hal-hal penting/isi dalam wawancara rekaman isi wawancara dan membuat tes hasil belajar.

b. Tahap tindakan

Kegiatan yang dilakukan dalam tahap ini adalah melaksanakan pembelajaran yang telah direncanakan dalam rencana pelaksanaan pembelajaran. Beberapa langkah-langkah yang dilakukan yaitu :

1. Peneliti menyampaikan tujuan pembelajaran

2. Peneliti menggali pengetahuan siswa mengenai materi sebelumnya

3. Peneliti menjelaskan penerapan model pembelajaran Group Investigation.

4. Peneliti menjelaskan cara menyimpulkan hasil wawancara atau isi wawancara dari narasumber.

5. Peneliti memberikan contoh wawancara yang diperdengarkan kepada siswa melalui alat rekaman.

6. Peneliti meminta siswa untuk menanyakan materi yang masih belum dipahami.

7. Peneliti memberikan kesimpulan materi.

c. Tahap observasi

Pada tahap observasi ini dilakukan secara bersamaan dengan pelaksanaan tindakan dan pengamat (guru bidang studi bahasa Indonesia) menggunakan lembar pedoman observasi.

d. Tahap refleksi

Pada tahap ini menganalisis hasil observasi, mengevaluasi hasil observasi, menganalisis hasil pembelajaran.

2. Pertemuan kedua terdiri dari:

a. Tahap perencanaan

Menyusun rencana pelaksanaan pembelajaran perbaikan pada awal pembelajaran pada siklus kedua yaitu menyiapkan lembar observasi dan media yang digunakan (alat rekaman) dan daftar penilaian siswa.

b. Tahap tindakan

1. Peneliti menjelaskan maksud pembelajaran dan tugas kelompok

2. Peneliti menjelaskan kembali materi tentang wawancara dan yang perlu diperhatikan dalam menulis hal-hal penting dalam wawancara

3. Peneliti membentuk lima kelompok kecil. Setiap kelompok terdiri dari 5 orang siswa

4. Peneliti memberikan contoh wawancara yang diperdengarkan lewat rekaman dan meminta kelompok menulis hal-hal penting yang terdapat dalam wawancara tersebut dalam bentuk kesimpulan singkat dan tepat

5. Peneliti menyuruh salah satu dari perwakilan dari setiap kelompok menyampaikan hasil diskusi kelompoknya 
6. Peneliti meminta kelompok lain berpartisipasi aktif dengan bertanya dan memberi tanggapan terhadap hasil diskusi kelompok yang tampil

7. Peneliti memberikan penjelasan singkat sekaligus memberikan kesimpulan mengenai tugas kelompok yang dibahas

8. Peneliti meminta siswa setiap kelompok membuat laporan akhir yang telah disempurnakan

c. Tahap observasi

Pada tahap observasi ini dilakukan secara bersamaan dengan pelaksanaan tindakan dan pengamat (guru bidang studi bahasa Indonesia) menggunakan lembar pedoman observasi

d. Tahap refleksi

Pada tahap ini menganalisis hasil observasi, mengevaluasi hasil observasi, dan menganalisis hasil pembelajaran.

\section{Kajian Pustaka \\ Pengertian menulis}

Menulis didefenisikan sebagai suatu kegiatan penyampaian pesan (komunikasi) dengan menggunakan bahasa tulis sebagai alat atau medianya. Selain itu, menurut damlan (2012:3) bahwa menulis merupakan suatu proses kreatif menuangkan gagasan dalam bentuk bahasa tulis dengan tujuan memberitahu, meyakinkan atau menghibur. Hasil dari proses kreatif ini biasa disebut dengan istilah karangan atau tulisan. Kedua istilah tersebut mengacu pada hasil yang sama meskipun ada pendapat yang mengatakan kedua istilah tersebut memiliki pengertian yang berbeda. Istilah menulis melekatkan pada proses kreatif yang sejenis ilmiah. Sementara istilah mengarang sering dilekatkan pada proses kreatif yang sejenis non ilmiah. Trimansyah dalam Kusmayadi (2007:7) meyakini bahwa kemampuan menulis itu bukan lahir karena bakat tetapi karena diciptakan.

Sejalan dengan pendapat diatas Marwoto dalam Damlan (2012:4) mengatakan "menulis adalah mengungkapkan ide atau gagasannya dalam bentuk karangan secara leluasan”. Kegiatan menulis membutuhkan skemata yang luas sehingga penulis mampu menuangkan ide, gagasan, pendapatnya dengan mudah dan lancar.

\section{Tujuan menulis}

Menulis memilki tujuan tersendiri, hal ini sangat bergantung kepada pembaca. Maka, beberapa para ahli mengemukakan beberapa pendapatnya. Kusmayadi (2007:6) mengemukakan beberapa tujuan menulis yaitu:

a. Tulisan yang bertujuan untuk memberitahukan atau mengajar disebut wacana informatif.

b. Tulisan yang bertujuan untuk meyakinkan atau mendesak disebut wacana persuasi.

c. Tulisan yang bertujuan untuk menghibur atau menyenangkan yang mengandung tujuan estetik disebut tulisan literer (wacana kesastraan) 
d. Tulisan yang mengekspresikan perasaan atau emosi yang kuat atau berapi-api disebut wacana ekspresi.

\section{Contoh wawancara:}

Contoh kutipan wawancara dan simpulan hal-hal penting / isi dalam wawancara.

Sari Asnat : "Selamat pagi, pak"

Bapak Agung : "Selamat pagi"

Sari Asnat : "Saya ingin bertanya seputar kesehatan tubuh, pak"

Bapak Agung : "Oh...iya. silahkan!"

Sari Asnat : "Menurut bapak, arti dari kesehatan tubuh itu apa?"

Bapak Agung : "Menurut saya, kesehatan tubuh adalah kondisi baik yang dimiliki oleh tubuh"

Sari Asnat : "Maksudnya kondisi baik?"

Bapak Agung : "Ya, artinya kita sedang tidak sakit. Tubuh kita sehat dan mampu untuk bekerja dan melakukan berbagai aktifitas sehari-hari"

Sari Asnat : "Seberapa penting kesehatan tubuh menurut bapak?"

Bapak Agung : "Kesehatan tubuh itu sangat penting. Bila selalu menjaga kesehatan tubuh, kita tidak akan mudah terserang penyakit. Selain itu, kita juga bisa banyak melakukan berbagai hal dan membuat prestasi."'।

Sari Asnat : "Apa saja yang harus dilakukan untuk menjaga kesehatan tubuh?"

Bapak Agung : "Menurut saya, cara untuk menjaga kesehatan tubuh itu dengan makan makanan bergizi, tidak sering makna makanan berlemak tinggi, banyak olahraga, istrahat cukup rutin pemeriksaan kesehatan ke dokter, dan berpikiran positif setiap harinya."

Sari asnat : Terima kasih waktu dan informasi yang bapak agung jelaskan seputar bagaimana menjaga kesehatan tubuh.

Bapak agung : Iya ..terima kasih.

Hal-hal penting yang terdapat dalam wawancara yaitu :

Narasumber : : Bapak agung

Topik wawancara : Kesehatan tubuh

Tujuan wawancara : Mengetahui pentingnya menjaga kesehatan tubuh

Pokok-pokok penting dalam isi wawancara yang dikemukakan narasumber diantaranya adalah sebagai berikut:

a. Kesehatan tubuh merupakan kondisi baik yang dimiliki oleh tubuh.

b. Kondisi baik adalah ketika tubuh tidak sakit dan bisa melakukan berbagai aktivitas sehari-hari.

c. Menjaga kesehatan tubuh itu sangat penting agar kita tidak mudah terserang penyakit dan bisa melakukan banyak hal dan juga berprestasi. 
d. Hal yang dilakukan untuk menjaga kesehatan tubuh adalah dengan makan makanan bergizi, istrahat yang cukup, rajin mengecek kesehatan pada dokter, banyak olahraga, dan selalau berpikiran positif.

\section{HASIL DAN PEMBAHASAN}

Penelitian tindakan kelas (PTK) ini dilaksanakan disekolah menengah pertama yang beralamat di Desa Lahusa Kecamatan Sirombu Kabupaten Nias Barat, secara keseluruhan Siswa Menengah Pertama. Sekolah Menengah Pertama memilki fasilitas belajar yang cukup memadai di antaranya : a). ruang kelas terdiri dari 3 ruangan serta ruang guru dan perpustakaan masing-masing 1 ruangan; dan b). tempat olahraga (voli , sepak bola, dan tenis meja) selain fasilitas sekolah, lingkungan sekitar juga cukup nyaman untuk mendukung aktivitas belajar siswa, guru dan masyarakat sekitar ikut memberi andil dalam kemajuan sekolah demi tercapainya pendidikan yang lebih baik. Selain itu, Sekolah Menengah Pertama memiliki prestasi-prestasi belajar siswa baik di tingkat kecamatan sampai provinsi. Hal ini terlihat dari beragam piala penghargaan yang berjejer diruang kantor guru Sekolah Menengah Pertama. Subjek penelitian yaitu siswa kelas VII, Semester II (dua).

Peningkatan kemampuan menulis hal-hal penting/isi dalam wawancara melalui model group investigation

a. Pembelajaran siklus I pertemuan pertama

Pembelajaran pada siklus I pertemuan pertama dilakukan dari tahap perencanaan, tindakan, observasi dan refleksi yaitu :

1. Perencanaan

Kegiatan yang dilakukan pada tahap perencanaan yaitu menyiapkan perangkat pembelajaran, menyiapkan materi mengenai menulis hal-hal penting/isi dalam wawancara model Group investigation. Membuat lembar observasi (siswa dan peneliti) untuk melihat bagaimana kondisi pembelajaran yang berlangsung di dalam kelas, menyiapkan daftar hadir siswa, media yang digunakan (alat rekaman). Penepatan waktu pelaksanaan yaitu rabu, 06 april 2016 dengan lamanya tindakan 2x40 menit (1 kali pertemuan).

2. Tindakan

Tindakan yang dilakukan dalam tahap ini adalah melaksanakan pembelajaran yang telah direncanakan oleh peneliti. Tindakan yang dilakukan dilakukan yaitu:

a. Peneliti menyapa siswa.

b. Peneliti memperkenalkan diri.

c. Peneliti menyampaikan tujuan pembelajaran.

d. Peneliti motivasi siswa terkait kegiatan pembelajaran.

e. Peneliti menjelaskan materi mengenai menulis hal-hal penting/isi dalam wawancara. 
f. Peneliti menjelaskan cara menyimpulkan hasil isi wawancara dari narasumber yang didengar dari rekaman.

g. Peneliti memberikan contoh wawancara yang diperdengarkan kepada siswa melalui alat rekaman.

h. Peneliti menjelaskan penerapan model pembelajaran group investigation.

i. Peneliti meminta siswa untuk menanyakan materi yang masih belum dipahami.

j. Peneliti menarik kesimpulan tentang materi yang diajarkan.

k. Peneliti menutup materi pembelajaran.

3. Observasi

Pada tahap ini, guru pengamat mengamati seluruh aktivitas siswa dan peneliti selama kegiatan belajar mengajar berlangsung. Dari hasi pengamatan diketahui beberapa kelebihan dan kelemahan siswa pada siklus I pertemuan pertama yaitu sebagai berikut.

a. Kelebihan siswa yaitu :

1. Siswa mendengar penjelasan materi dari peneliti.

2. Sebagian besar mencatat materi yang disampaikan oleh peneliti.

3. Beberapa siswa antusias belajar dalam kegiatan belajar.

4. Terdapat siswa yang memberikan pendapat terkait materi.

5. Terdapat siswa yang mampu mengajukan pertanyaan.

b. Kelemahan siswa yaitu :

1. Adanya siswa yang kurang memahami materi pembelajaran yang disampaikan oleh peneliti.

2. Adanya beberapa siswa tidak mencatat materi yang disampaikan oleh peneliti.

3. Siswa masih belum terbiasa belajar dalam kelompok karena perbedaan persepsi dan kemampuan dari masing-masing siswa kelas VII Sekolah Menengah Pertama. Sebagian besar siswa masih ragu menyampaikan pendapat.

4. Kebanyakan siswa yang tidak berani mengajukan pertanyaan terkait materi yang disampaikan peneliti.

5. Adanya siswa yang tidak sunguh-sungguh mengikuti kegiatan pembelajaran yang disampikan peneliti.

6. Kebanyakan siswa tidak menentukan hal-hal penting/isi dalam wawancara dari contoh rekaman yang diperdengarkan oleh peneliti.

Berdasarkan hasil observasi pengamatan guru mata pelajaran guru bahasa Indonesia kepada siswa Sekolah Menengah Pertama, diperoleh hasil observasi aktivitas siswa dari siklus I pertemuan pertama yaitu rata-rata $62,82 \%$ 


\section{Refleksi}

Berdasarkan hasil observasi pada siklus I pertemuan pertama, dapat diambil kesimpulan bahwa belum menunjukkan adanya peningkatan proses pembelajaran yang memuaskan seperti yang diharapkan. Ini berdasarkan kelemahan-kelemahan yang ditemukan pada pelaksanaan siklus I pertemuan pertama. Maka, sebelum melanjutkan siklus I pertemuan II, peneliti bekerjasama dengan kolaborator guru pengamat melakukan perbaikan dari kelemahankelemahan pada siklus I pertemuan pertama untuk pertemuan berikutnya yakni siklus I pertemua kedua. Hasil dari perbaikan untuk melanjutkan siklus I pertemuan kedua yaitu :

a. Peneliti menjelaskan materi pembelajaran secara mendetail .

b. Peneliti memotivasi siswa lebih aktif dengan memberikan pendapatnya.

c. Peneliti mengarahkan siswa betapa pentingnya kerjasama antara satu dengan yang lain dalam satu kelompok untuk memecahkan masalah.

d. Peneliti memotivasi siswa berani menyampaikan pertanyaannya.

e. Peneliti menasehati siswa agar sungguh-sungguh mengikuti proses pembelajaran.

f. Peneliti mengajak siswa secara keseluruhan berpartisipasi aktif dalam mengikuti proses pembelajaran.

g. Peneliti meminta siswa lebih percaya diri dan bertanggung jawab menyelesaikan tugas tanpa menuntut jawaban yang sempurna.

\section{KESIMPULAN}

Berdasarkan hasil temuan penelitian dan hasil analisis maka peneliti menarik beberapa kesimpulan yaitu : (1). Pada siklus I peningkatan kemampuan siswa menulis hal-hal penting/isi dalam wawancara mendapat nilai terendah yaitu 30 dan nilai tertinggi 80 dengan rata-rata 58,65 sedangkan pada siklus kedua peningkatan kemampuan siswa menulis hal-hal penting/isi dalam wawancara nilai terendah yaitu 70 dan nilai tertinggi 95 dengan rata-rata 81,73 ; (2). Pada siklus I observasi dari keaktifan siswa pada pertemua pertama yaitu $62,82 \%$ dan pada pertemuan kedua yaitu $72,12 \%$ sedangkan pada siklus II hasil observasi dari keaktifan pertemua pertama yaitu 82,05\% dan pada pertemuan kedua yaitu 95,19\%; (3). Dengan menggunakan model Group investigation dapat meningkatkan kemampuan siswa menulis hal-hal penting/isi dalam wawancara siswa kelas VII Sekolah Menengah Pertama; dan (4). Dengan menggunakan model Group Investigation dapat memberikan motivasi belajar siswa, kerjasama antara siswa dan siswa dengan guru semakin baik.

\section{SARAN}

Saran yang diberikan oleh peneliti berdasarkan temuan peneliti adalah diantaranya: (1). Guru sebagai pendidik diharapkan mampu menjalankan perannya sebagai fasilitator, organisator, dan motivator bagi siswa sehingga menambah antusias belajar siswa serta mampu menggunakan berbagai model atau metode pembelajaran sesuai materi yang diajarkan, sehingga dapat menciptakan suasana belajar yang- 
menyenangkan dan dapat meningkatkan hasil belajar siswa; (2). Diharapkan dengan penerapkan model Group Investigation siswa mampu berkolaborasi bersama melakukan analisis, mengembangkan rasa sosial, mencari solusi, serta mengidentifikasikan maslah yang dihadapi dalam proses belajar mengajar.

\section{DAFTAR PUSTAKA}

Anindyarini, Atikah, dan Ningsih, 2008, Buku Bahasa Indonesia, Departemen pendidikan, Jakarta. Asmani, Jamal, Ma'mur, 2011, Penelititan Tindakan Kelas, Laksana, Jokjakarta.

Catarina, 2005, Bahasa Indonesia SMP kelas VII dan IX, Pustaka Pelajar, Yogyakarta.

Dakhi, O. "Aplikasi Pendeteksian Kerusakan File Akibat Virus Dengan Menggunakan Metode Heuristic." Pelita Informatika Budi Darma, vol. 4, no. 1, pp. 35-41, 2013.

Dakhi, O. 2013. Belajar Javascript Dengan Mudah Dan Detail. Jakarta: Dapur Buku. pp. 1-202. Damlan, 2012, Keterampilan Menulis,PT Raja Grafindo Persada, Jakarta.

Istarani, 2011, Model Pembelajaran Inovatif, Media Persada Medan.

Kusmayadi, Ismail, 2007, Menulis Dengan Hati Membangun Motivasi Menulis, PT. Pribumi Mekar Bandung.

Laia, Askarman, 2009, Upaya Meningkatkan Kemampuan Siswa Menulsi Pragraf Dengan Penerapan Model Pembelajaran Gorup Investigation di SMP Negeri IX Telukdalam, Tidak di Terbitkan Program Sarjana, IKIP Gunungsitoli.

Nurgiyanotro, Burhan, 2010, PenilaianPembelajaran Bahasa, BPFE-Yogyakarta, Yogyakarta.

Nurhadi, Dawud, dan Pratiwi, 2007, Buku Bahasa Indonesia untuk SMP kelas VII, Erlangga, Malang.

Sarumaha, R., Harefa, D., \& Zagoto, Maria M. (2018). Upaya Meningkatkan Kemampuan Pemahaman Konsep Geometri Transformasi Refleksi Siswa Kelas XII-IPA-B SMA Kampus Telukdalam Melalui Model Pembelajaran Discovery Learning Berbantuan Media Kertas Milimeter. Jurnal Education and development, Vol.6 No.1, 90-96. https://doi.org/10.37081/ed.v6i1.668

Sbaran, 1984, Model Penelitian, (online), (http://Ibrahim,ipos,wordspress.com, Diakses Pada 4 Januari 2016).

Suparno, dkk, 2003, Keterampilan Dasar Menulis Universitas Terbuka, Kementrian Pendidikan dan Kebudayaan, Jakarta.

Suryanto, Alex, dan Haryanta, 2007, Buku Panduan Belajar Bahasa Dan Sastra Indonesia, Erlangga, Tangerang.

Tarigan, 1982, Menulis Sebagai Suatu Keterampilan Berbahas, Angkasa, Bandung.

Wena, Made, 2008, Strategi Pembelajaran Inovatif Kontemporer Suatu Tinjauan Konseptual Operasional, PT. Bumi Aksara Malang.

Zagoto, Maria M., Yarni, Nevi; Dakhi, O. (2019). Perbedaan Individu dari Gaya Belajarnya Serta Implikasinya Dalam Pembelajaran. Jurnal Review Pendidikan dan Pengajaran, 2(2), 259265.

Zagoto, Maria M. \& Dakhi, O (2018). Pengembangan Perangkat Pembelajaran Matematika Peminatan Berbasis Pendekatan Saintifik Untuk Siswa Kelas XI Sekolah Menengah Atas. Jurnal Review Pendidikan dan Pengajaran, 1(1), 157-170.

Zagoto, Maria M. (2018). Pengembangan Perangkat Pembelajaran Matematika Berbasis Realistic Mathematic Educations Untuk Siswa Kelas V Sekolah Dasar, Jurnal Education And Development, vol. 3, no. 1, p. 53, Feb. 2018. https://doi.org/10.37081/ed.v3i1.139

Zebua, Adaria, 2009, Upaya Meningkatkan Minat Belajar Bahasa Indonesia Melalui Metode Pembelajaran Group Investigation (GI) Siswa Kelas IX SMP Negeri 1 Amandraya. 